\title{
Rapid diagnosis of malignancy using flow cytometry
}

\author{
D M Williams, S O'Connor, J W Grant, R E Marcus, V Broadbent
}

\begin{abstract}
The rapid and accurate diagnosis of childhood malignancy is important both in the planning of appropriate treatment and in relieving the inevitable family anxiety. The use of flow cytometry to analyse monoclonal antibody coated single cell suspensions is widely accepted as having increased the speed and accuracy of diagnosis in leukaemias, though its use in solid tumour diagnosis is not widely reported.

Ten cases of childhood malignancy in whom the diagnosis was initially made by flow cytometry and subsequently confirmed histologically are described. The technique has a number of advantages. Only a small sample is required as the analysis is carried out on a single cell suspension, the method is rapid, a diagnosis being reached within three hours of receipt of the sample, and information is obtained on cell lineage and stage of differentiation. Diagnostic accuracy is good when compared with histological results.

(Arch Dis Child 1993; 68: 393-398)
\end{abstract}

The recent use of monoclonal antibodies (MoAbs) has greatly improved the accuracy of diagnosis of many haematological malignancies as well as some solid tumours. ${ }^{1-3}$ However their use in solid tumour diagnosis, even with modern histological techniques, is time consuming and often takes days to reach a definitive answer. The use of flow cytometry to analyse MoAb coated single cell suspensions obtained from solid tissue samples has greatly improved the speed of diagnosis of solid tumours allowing appropriate treatment to start without long delays. ${ }^{4}$

We report here 10 such cases of childhood malignancy in whom the diagnosis was made initially by flow cytometry and subsequently confirmed by standard histological analysis.

\section{Case reports}

CASE 1

Addenbrookes Hospital, Cambridge CB2 2QQ

Department of Paediatrics

D M Williams

V Broadbent

Department of

Haematology

S O'Connor

R E Marcus

Department of Histopathology

J W Grant

Correspondence to:

Dr Williams.

Accepted 3 October 1992 examination $4 \times 5 \mathrm{~cm}$ mass was palpated overlyance imaging scan showed the mass enveloping the left masseter muscle and extending anteriorly along the line of the mandible. A chest $x$ ray film, abdominal ultrasound, and bone scans showed no other site of disease. Bone marrow aspirate and cerebrospinal fluid cytospin were both normal. A provisional differential diagnosis of rhabdomyosarcoma or non-Hodgkin's lymphoma or was made. The mass was biopsied and fresh tissue sent for both histology and analysis by flow cytometry.
CASE 2

A boy presented first at the age of 8 years with common acute lymphoblastic leukaemia. He was treated with the Medical Research Council (MRC) UKALL VIII protocol that included cranial irradiation and a randomisation to stop maintenance treatment at two years. Five months after completing treatment he had a cranial and testicular relapse, was reinduced on UKALL VIII, and received both craniospinal and testicular irradiation. He had remained well off treatment for almost three years but then he presented with a painless left sided facial swelling. Examination revealed a $4 \mathrm{~cm}$ firm mass at the angle of the mandible. A parotid sialogram showed a normal duct pattern but a computed tomogram revealed an enlarged/infiltrated left masseter. The differential diagnosis was of a second tumour, non-Hodgkin's lymphoma or a rhabdomyosarcoma, or a further leukaemic relapse. The mass was biopsied.

CASE 3

A boy presented aged 2 years with a six week history of abdominal swelling and malaise. On examination he was grossly hypertensive with a blood pressure of $210 / 310 \mathrm{~mm} \mathrm{Hg}$, had a large left sided abdominal mass, which on computed tomogram displaced the aorta and compressed/ infiltrated the left kidney. Bone marrow aspiration showed no infiltration and urinary vanillylmandelic acid (VMA) was equivocally raised. The provisional clinical diagnosis was of a neuroblastoma or a Wilms' tumour. Needle biopsy was performed under computed tomogram control.

\section{CASE 4}

A girl presented aged 2 years with a two month history of fevers, weight loss, and increasing abdominal distension. On examination she was normotensive but had a large right sided abdominal mass. A computed tomogram showed the mass extending into the right flank and displacing the right kidney. Flecks of calcification were seen within the mass. A bone marrow aspirate showed no infiltration and urinary VMA was not raised. The provisional clinical diagnosis was of a neuroblastoma or a sarcoma, and an open biopsy was performed. ing the left masseter muscle. A magnetic reson-
CASE 5

A boy was 15 years when he presented with a one month's history of a left posterior auricular mass. He had no associated symptoms. A computed tomogram showed a large soft tissue mass adjacent to the lamina of $\mathrm{C} 1$ vertebra extending inferiorly to $\mathrm{C} 2$ and cranially to the external auditory meatus. Staging investigations including a bone marrow aspirate were normal. The 
differential clinical diagnosis was of a rhabdomyosarcoma or non-Hodgkin's lymphoma. He underwent open biopsy.

CASE 6

An 11 year old boy complained of six weeks of fatigue, anorexia, and cervical lymphadenopathy. On examination he had an $8 \mathrm{~cm}$ nontender swelling at the angle of the right jaw and a left supraclavicular node. Imaging showed no other lymphadenopathy, a bone marrow aspirate and cerebrospinal fluid cytospin were both normal. Histologically a node biopsy showed a T cell lymphoma, although flow cytometry was inconclusive. He was treated according to the MRC UKALL X schedule and had a good initial response. Fifteen weeks into treatment he developed further cervical lymphadenopathy and was rebiopsied. The provisional clinical diagnosis was resistant $\mathrm{T}$ cell lymphoma.

CASE 7

A girl presented aged 6 years with a five day history of abdominal pain and a three day history of abdominal swelling. On examination she had bilateral pleural effusions, gross ascites, a $6 \mathrm{~cm}$ palpable liver edge, a large left sided pelvic mass, and inguinal lymphadenopathy. A computed tomogram confirmed bilateral pleural effusions, a soft tissue mass engulfing the internal mammary chains, a large mass in the coeliac territory, massive para aortic disease, and bilateral pelvic masses. Cerebrospinal fluid cytospin showed no abnormal cells and a bone marrow aspirate was morphologically normal. A provisional diagnosis of lymphoma was made. A biopsy was taken under computed tomogram control and both tissue and pleural fluid sent for flow cytometry.

CASE 8

A boy presented at the age of 10 years with a short history of lethargy, anorexia, and intermittent abdominal pain. On examination he had a distended abdomen with a $13 \mathrm{~cm}$ liver and a $3 \mathrm{~cm}$ spleen. A computed tomogram of his abdomen showed a grossly enlarged liver with multiple low attenuation areas and a single splenic lesion. There was no lymphadenopathy. A chest $x$ ray film showed no mediastinal nodes. Bone marrow aspirate and cerebrospinal fluid cytospin were both normal. The liver was biopsied under computed tomogram control and a clinical diagnosis of non-Hodgkin's lymphoma was made.

CASE 9

A girl presented at the age of 11 years with a six week history of increasing cervical lymphadenopathy, nocturnal fevers, and a dry cough. On examination she had gross cervical lymphadenopathy and evidence of superior vena cava obstruction. A chest $x$ ray film and computed tomogram showed a large anterior mediastinal mass and a left sided pleural effusion. Bone marrow aspirate and cerebrospinal fluid cytospin showed no abnormal cells. A provisional clinical diagnosis of lymphoma was made. Pleural fluid was aspirated and sent for analysis by flow cytometry.

CASE 10

A boy presented at the age of 12 years with a three month history of a dry cough and breathlessness and a one day history of facial swelling. On examination he had gross cervical and left axillary lymphadenopathy and evidence of superior vena cava obstruction. A chest $x$ ray film and ultrasound scan showed a large mediastinal mass and a left pleural effusion. Bone marrow aspirate and cerebrospinal fluid cytospin were both normal. A provisional clinical diagnosis of lymphoma was made. Pleural fluid was sent for flow cytometry.

\section{Methods}

\section{(1) COLLECTION OF SAMPLES}

Fresh tissue (no preservative, fixative, or anticoagulant) was collected in eight patients: five by open biopsy and three by needle biopsy. In cases 9 and 10 only pleural fluid was analysed.

\section{(2) FLOW CYTOMETRY}

\section{(A) Sample preparation}

The average size of the biopsy sample received was $2 \mathrm{~mm} \times 5 \mathrm{~mm}$. Two dab preparations were done as soon as the sample was received, one was stained with May-Grünwald Giemsa stain and examined microscopically. The solid tissue sample was then disaggregated by teasing the sample against $0.2 \mathrm{~mm}$ pore size steel mesh using phosphate buffered saline with $0.05 \%$ albumin (PBS/A) as diluent to produce a single cell suspension. The cells were then washed twice in PBS/A and layered onto a ficoll density gradient (Sigma Histopaque 1077) to select for viable mononuclear cells and centrifuged at $800 \mathrm{~g}$ for 25 minutes. The mononuclear cells were extracted from the interface and washed twice in PBS/A. A cell count was obtained from the Coulter STKS. The cell concentration was adjusted to $1-2 \times$ $10^{9} / 1$ using PBS/A as a diluent. The cells were kept on ice until they were labelled. The minimum number of cells needed for a complete immunophenotyping panel detailed below is $1 \times 10^{7}$ cells. All our patients studied, except for case 3 , had cell counts higher than this (range $1 \times 10^{7}$ to $350 \times 10^{7}$ cells). Case 3 had a cell count of $0.5 \times 10^{7}$ but with clinical information and morphology from the dab preparation it was possible to tailor the panel of MoAbs used and a diagnosis was reached.

\section{(B) Monoclonal antibodies}

MoAbs, unless otherwise stated, were all obtained from Dako Ltd.

The first line panel of MoAbs for all cases consisted of CD2 ( $\mathrm{T}$ cell), CD10 (common acute lymphoblastic leukaemia antigen), CD19 (pan B cell), CD45 (leucocyte common antigen) and HLA-DR ( $B$ cell and activated $T$ cell). The 
second line panel was selected based on the results of the first panel. For B lineage this was CD20, CD22, CD25, FMC7, surface IgM, cytoplasmic IgM, $x$, and $\lambda$. For T lineage this was $\mathrm{CD} 1, \mathrm{CD} 3, \mathrm{CD} 4, \mathrm{CD} 5, \mathrm{CD} 7$, and CD8. If CD1 was positive then dual labelling for CD4 and CD8 was performed using CD4 fluorescein conjugate (FITC) and CD8 phycoerythrin conjugate obtained from Becton-Dickinson with an FITC and phycoerythrin conjugate mouse Ig matched control.

For non-haematological cells the second panel consisted of UJ13a for neurofilament protein (obtained from Dr J Kemshead, Institute of Child Health), desmin a striated muscle cell marker, vimentin for cells of mesenchymal origin, and cytokeratin for cells of epithelial origin. Non-lineage antibodies also used included CD34 for stem cells, Tdt for early T, B, and myeloid cells and $\mathrm{Ki}-67$ for proliferating cells. FITC conjugated rabbit antimouse was used as a second stage bridging antibody.

\section{(C) Immunophenotyping and flow cytometry}

Labelling was carried out by incubating $50 \mu \mathrm{l}$ of cell suspension of $1-2 \times 10^{9} / 1$ concentration with $10 \mu \mathrm{l}$ of MoAb. A negative control was set up for each patient. The panel was incubated on ice for 30 minutes. The cells were washed twice with ice cold PBS/A and then fixed by adding $400 \mu \mathrm{l}$ of $0.5 \%$ formaldehyde in PBS/A. The cells were then immediately analysed. Flow cytometry was performed using a FACScan fitted with an air cooled argon ion laser of $15 \mathrm{~mW}$ power at $488 \mathrm{~nm}$ (Becton-Dickinson Immunocytometry Systems,
BDIS). Acquisition and analysis of results obtained was performed using BDIS Consort 30 software. The instrument was set up according to the manufacturers instructions. A total of 10000 cells were collected and saved in Listmode format for each antibody. Cell identification was carried out by analysing forward angle light scatter, a measure of cell size and $90^{\circ}$ or side angle light scatter, a measure of cell granularity. The cells of interest were gated and the gated population of mononuclear cells were then analysed for fluorescence. A level of $2 \%$ fluorescence of the negative control sample was considered acceptable. The panel was analysed and the results expressed as a \% positivity of the gated mononuclear cells. A result of $<5 \%$ was classified as negative, $5-25 \%$ inconclusive requiring further study, and $>25 \%$ positivity was classified as a positive result. In all our cases the percentage positivity was in excess of $35 \%$.

\section{(3) HISTOPATHOLOGY}

Biopsy specimens were received unfixed in the laboratory. Part of the specimen was snap frozen in liquid nitrogen and stored at $-70^{\circ} \mathrm{C}$ for immunohistochemical analysis. The remaining material was fixed in $10 \%$ neutral buffered formalin. Paraffin embedded tissue was stained with haematoxylin-eosin, periodic acid-Schiff, reticulin, and haematoxylin-van Gieson. Immunophenotyping was performed on both frozen and paraffin embedded tissue, using biotinylated swine antirabbit immunoglobulin as the second and streptavidin biotin complex as the third layer. When frozen tissue was used, $5 \mu \mathrm{m}$

Clinical diagnoses compared with histological examination and flow cytometry

\begin{tabular}{|c|c|c|c|c|c|c|}
\hline $\begin{array}{l}\text { Patient } \\
\text { No }\end{array}$ & $\begin{array}{l}\text { Age } \\
\text { (years) }\end{array}$ & Clinical diagnosis & Tissue analysed & Flow cytometry & Histology & Final diagnosis \\
\hline 1 & 6 & $\begin{array}{l}\text { Non-Hodgkin's lymphoma/ } \\
\text { rhabdomyosarcoma }\end{array}$ & $\begin{array}{l}\text { Biopsy of masseter } \\
\text { mass }\end{array}$ & $\begin{array}{l}\mathrm{CD} 10+\mathrm{ve}, \mathrm{CD} 19+\mathrm{ve} \\
\text { desmin -ve }\end{array}$ & $\begin{array}{l}\text { Infiltration with lymphoid } \\
\text { cells. Staining for B and T } \\
\text { cell markers - ve }\end{array}$ & $\begin{array}{l}\text { Consistent with extramedullary } \\
\text { presentation of common } \\
\text { acute lymphoblastic } \\
\text { leukaemia }\end{array}$ \\
\hline \multirow[t]{3}{*}{2} & 8 & $\begin{array}{l}\text { Common acute } \\
\text { lymphoblastic leukaemia }\end{array}$ & & & & \\
\hline & 11 & $\begin{array}{l}\text { Cranial and testicular } \\
\text { relapse }\end{array}$ & & & & \\
\hline & 15 & $\begin{array}{l}\text { Rhabdomyosarcoma/non- } \\
\text { Hodgkin's lymphoma }\end{array}$ & $\begin{array}{l}\text { Biopsy of masseter } \\
\text { mass }\end{array}$ & $\begin{array}{l}\text { Two cell populations. CD10 } \\
\text { +ve, CD19 + ve, CD5 + ve, } \\
\text { CD2 + ve }\end{array}$ & $\begin{array}{l}\text { Infiltration with lymphoid } \\
\text { cells. T cells markers + ve }\end{array}$ & $\begin{array}{l}\text { Consistent with an } \\
\text { extramedullary relapse of } \\
\text { common acute lymphoblastic } \\
\text { leukaemia }\end{array}$ \\
\hline 3 & 2 & $\begin{array}{l}\text { Neuroblastoma/Wilms' } \\
\text { tumour }\end{array}$ & Needle biopsy & $\begin{array}{l}\text { Non-haematological in origin. } \\
\text { UJ13a strongly + ve }\end{array}$ & $\begin{array}{l}\text { Small round cell tumour. } \\
\text { Neurone specific enolase } \\
\text { stain + ve. UJ13a stain } \\
\text { equivocal }\end{array}$ & $\begin{array}{l}\text { Consistent with a diagnosis of } \\
\text { neuroblastoma }\end{array}$ \\
\hline 4 & 2 & Sarcoma/neuroblastoma & Open biopsy & $\begin{array}{l}\text { Non-haematological cells. } \\
\text { Vimentin + ve. UJ13a + ve }\end{array}$ & $\begin{array}{l}\text { Small round cell tumour. } \\
\text { Vimentin + ve. UJ13a + ve }\end{array}$ & $\begin{array}{l}\text { Consistent with PNET or } \\
\text { neuroblastoma }\end{array}$ \\
\hline 5 & 15 & $\begin{array}{l}\text { Rhabdomyosarcoma/non- } \\
\text { Hodgkin's lymphoma }\end{array}$ & Open biopsy & $\begin{array}{l}\text { Non-haematological in origin. } \\
\mathrm{Ki}-67+\mathrm{ve} \text {, desmin + ve }\end{array}$ & $\begin{array}{l}\text { Poorly differentiated } \\
\text { embryonal } \\
\text { rhabdomyosarcoma. } \\
\text { Desmin stain + ve }\end{array}$ & $\begin{array}{l}\text { Consistent with a highly } \\
\text { proliferative poorly } \\
\text { differentiated } \\
\text { rhabdomyosarcoma }\end{array}$ \\
\hline \multirow[t]{2}{*}{6} & 11 & $\begin{array}{l}\text { Hodgkin's disease/non- } \\
\text { Hodgkin's lymphoma }\end{array}$ & Node biopsy & $\begin{array}{l}\text { Inconclusive. ? reactive, } \\
\text { ? malignant }\end{array}$ & $\begin{array}{l}\text { Malignant T cell lymphoma. } \mathrm{T} \\
\text { cell marker positive }\end{array}$ & Malignant T cell lymphoma \\
\hline & & & $\begin{array}{l}\text { Repeat node biopsy at } \\
\text { week } 15 \text { of treatment }\end{array}$ & $\begin{array}{l}\mathrm{CD} 2+\mathrm{ve}, \mathrm{CD} 3 \text { + ve, } \mathrm{CD} 5 \\
\text { +ve, CD } 7 \text { + ve }\end{array}$ & $\begin{array}{l}\text { Malignant T cell lymphoma. } \\
\mathrm{T} \text { cell marker + ve }\end{array}$ & $\begin{array}{l}\text { Consistent with T cell non- } \\
\text { Hodgkin's lymphoma }\end{array}$ \\
\hline 7 & 6 & $\begin{array}{l}\text { B cell non-Hodgkin's } \\
\text { lymphoma }\end{array}$ & $\begin{array}{l}\text { Pleural fluid. Needle } \\
\text { biopsy of abdominal } \\
\text { mass }\end{array}$ & $\begin{array}{l}\text { CD19 + ve, CD10 + ve, } \\
\text { surface IgM + ve }\end{array}$ & $\begin{array}{l}\text { Morphology consistent with B } \\
\text { cell lymphoma. Lymphoid } \\
\text { markers unhelpful }\end{array}$ & $\begin{array}{l}\text { B cell non-Hodgkin's } \\
\text { lymphoma }\end{array}$ \\
\hline 8 & 10 & $\begin{array}{l}\text { B cell non-Hodgkin's } \\
\text { lymphoma }\end{array}$ & Liver biopsy & $\begin{array}{l}\text { CD45 + ve, } \mathrm{CD} 10 \text { + ve, } \mathrm{CD} 19 \\
\text { + ve, surface IgM + ve }\end{array}$ & $\begin{array}{l}\text { Morphology consistent with } \\
\text { B cell non-Hodgkin's } \\
\text { lymphoma. B cell markers } \\
\text { +ve }\end{array}$ & $\begin{array}{l}\text { B cell non-Hodgkin's } \\
\text { lymphoma }\end{array}$ \\
\hline 9 & 11 & $\begin{array}{l}\text { T cell non-Hodgkin's } \\
\text { lymphoma }\end{array}$ & Pleural fluid & $\mathrm{CD} 4+\mathrm{ve}, \mathrm{CD} 8+\mathrm{ve}, \mathrm{CD} 1+\mathrm{ve}$ & & $\begin{array}{l}\text { Consistent with T cell non- } \\
\text { Hodgkin's lymphoma, } \\
\text { common thymocyte } \\
\text { phenotype }\end{array}$ \\
\hline 10 & 12 & $\begin{array}{l}\text { T cell non-Hodgkin's } \\
\text { lymphoma }\end{array}$ & Pleural fluid & $\mathrm{CD} 4+\mathrm{ve}, \mathrm{CD} 8+\mathrm{ve}, \mathrm{CD} 1+\mathrm{ve}$ & & $\begin{array}{l}\text { Consistent with T cell non- } \\
\text { Hodgkin's lymphoma, } \\
\text { common thymocyte } \\
\text { phenotype }\end{array}$ \\
\hline
\end{tabular}




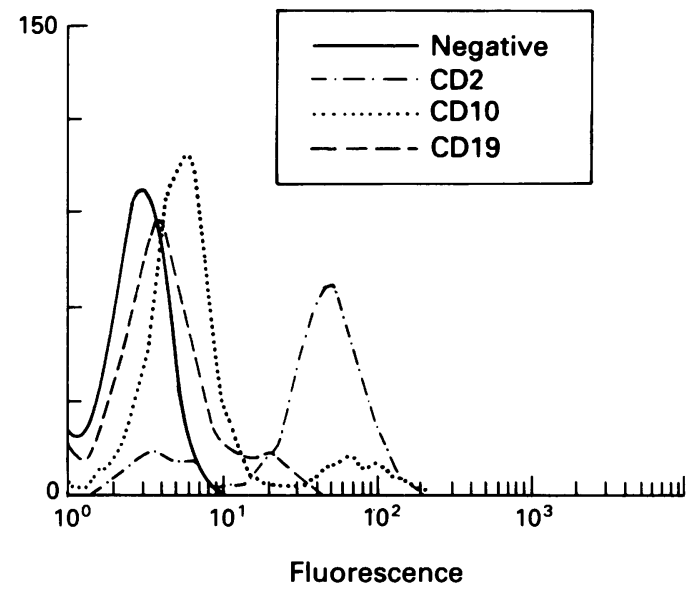

Figure 1 Case 2. Histogram format of increasing fluorescence with fluorescein labelled MoAbs CD2, CD10, and CD19 on the gated population of small cells. A population of CD2 positive cells are seen.

cryostat sections were fixed in acetone for 10 minutes. The MoAbs used were as follows: Dako LC staining leucocytes, antibodies to $\mathrm{T}$ cell antigens, CD3, UCHL1 (Dako), and MT1 (Bionuclear Services), to B cell antigens MB2 (Bionuclear Services), L26 (Dako) as well as antibodies to surface IgG, IgM, IgA, $x$ and $\lambda$ light chains. UJ13a (Institute of Child Health), neurone specific enolase (Dako) and PGP 9.5 (Biogenesis) were monoclonals used to detect neuroectodermal cells. Antibodies to desmin (Dako) and myoglobin (Dako) identified muscle tissue. Cam 5·2 (Becton Dickinson) was used as an anticytokeratin antibody recognising epithelial cells.

\section{Results}

The table compares the provisional clinical diagnoses with the results of both histological examination and flow cytometry.

Histology in cases 1 and 2 was equivocal, thought to be of uncertain lineage in case 1 and probably $T$ cell in case 2 . In case 1 by flow cytometry analysis, the cells were found to be of $\mathrm{B}$ cell origin expressing both CD10 and CD19. Surface IgM was negative, strongly suggesting an extramedullary presentation of common acute lymphoblastic leukaemia rather than $B$ cell

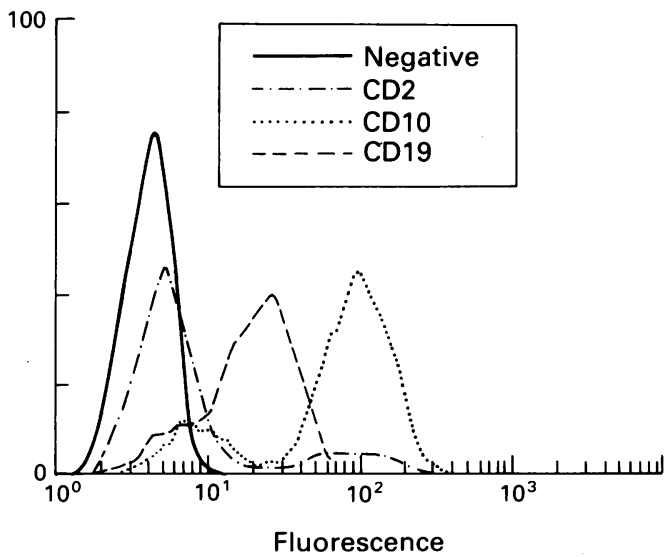

Figure 2 Case 2. Histogram format of increasing fluorescence with fluorescein labelled MoAbs CD2, CD10, and CD19 on the gated populaton of larger cells. A population of cells coexpressing $C D 10$ and $C D 19$ are seen.

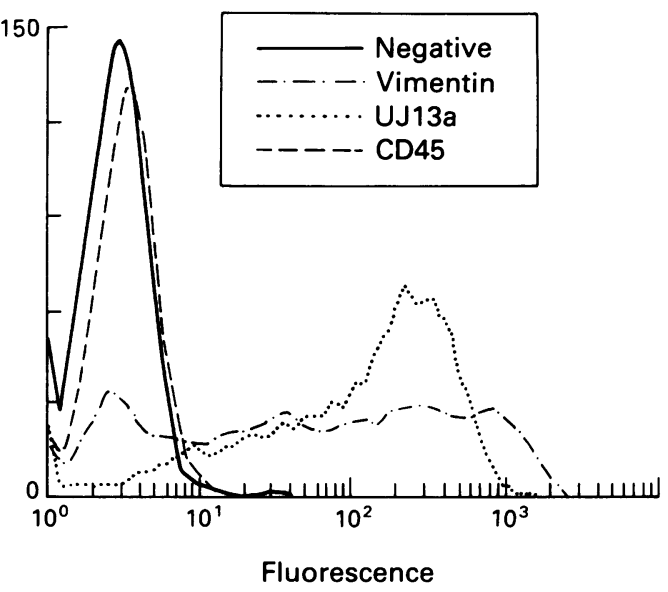

Figure 3 Case 4 (abdominal mass). Histogram format of increasing fluorescence with fluorescein labelled MoAbs vimentin, UY $13 a$, and CD45 on a gated population of cells. The cells express both vimentin and UF13a and are negative for $C D 45$.

lymphoblastic leukaemia. Case 2 was thought initially to be a $\mathrm{T}$ cell lymphoma. However, flow cytometry identified two cell populations; a T cell population of small cells expressing CD2 (fig 1) and a second $B$ cell population expressing CD19. This latter population was also CD10 positive (fig 2) suggesting the tumour was of $B$ lymphoblastic origin with an admixture of reactive $\mathrm{T}$ cells. ${ }^{5}$ This confirmed the masseter mass to be a relapse of his common acute lymphoblastic leukaemia rather than a second malignancy. Gene rearrangement studies subsequently demonstrated a rearrangement of the immunoglobulin heavy chain confirming a clonal B cell population. These cases have been published elsewhere. ${ }^{6}$

Cases 3 and 4 both presented as abdominal masses. By flow cytometry the cells were negative with $B, T$, myeloid markers and leucocyte common antigen (CD45) and were threfore, nonhaematological in origin. They both expressed UJ13a consistent with a diagnosis of neuroblastoma. ${ }^{7}$ In case 4 , the cells were also vimentin positive suggesting sarcomatous elements (fig 3). Histologically both these tumours were small round cell tumours. In case 3 , although the

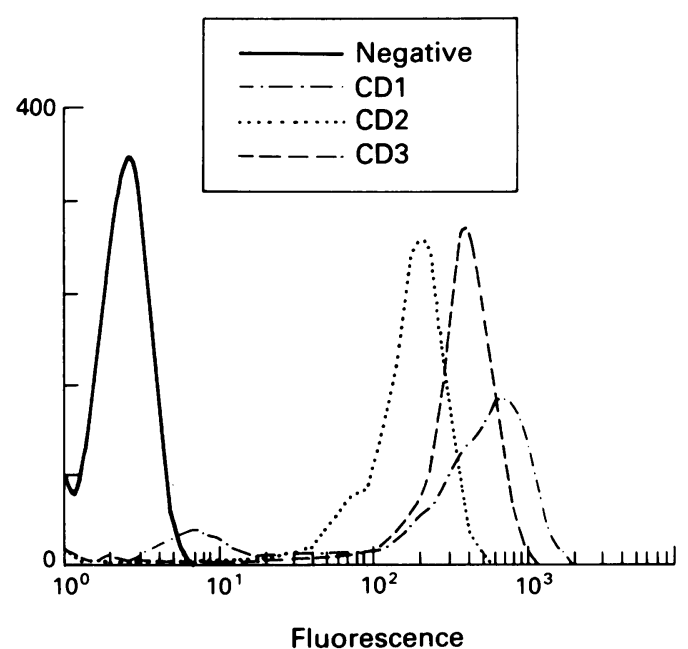

Figure 4 Case 10 (pleural fluid). Histogram format of increasing fluorescence with fluorescein labelled MoA bs CDI, $C D 2$, and $C D 3$. 


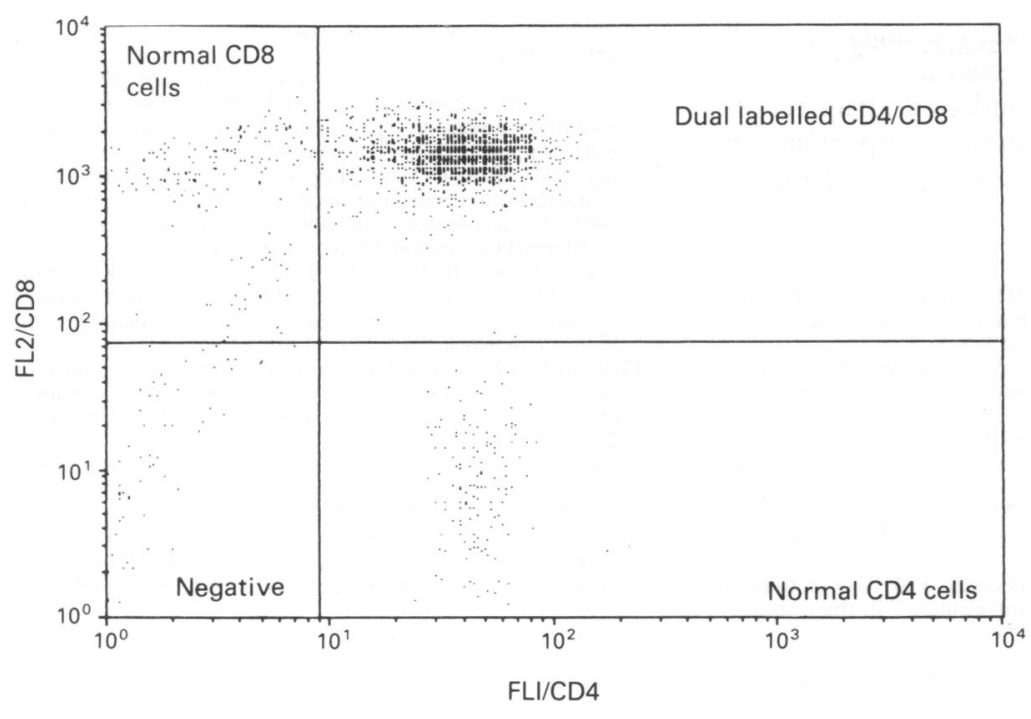

Figure 5 Case 10. Scatterplot of gated population of cells looking at fluorescence using fluorescein labelled CD4 (FL 1/CD4) against phycoerythrin labelled CD8 (FL2/CD8). Dual labelling with CD4 and CD8 of the cells is seen.

neurone specific enolase stain was positive supporting the diagnosis of neuroblastoma, UJ13a staining by immunoperoxidase was equivocal. In case 4 cell markers were similar using both methods consistent with a diagnosis of neuroblastoma.

In case 5 , both flow cytometry and histological examination were consistent with a diagnosis of a poorly differentiated rhabdomyosarcoma, the cells expressing desmin. Using flow cytometry $45 \%$ of the cells expressed $\mathrm{Ki}-67$, a frequent finding in rapidly proliferating solid tumours. ${ }^{8}$

In only case 6 was there doubt about diagnosis using flow cytometry. On the first biopsy specimen $\mathrm{T}$ cell non-Hodgkin's lymphoma was diagnosed histologically, with positive $\mathrm{T}$ cell markers. Flow cytometry was inconclusive failing to differentiate between reactive and malignant change. The sample of tissue received for analysis showing positivity for $B$ and $T$ cell markers. Flow cytometry was performed again on the second biopsy performed 15 weeks into treatment and cells were found to express CD2, CD3, CD5, and CD7. This phenotype is characteristic of a post-thymic or peripheral $\mathrm{T}$ cell malignancy as CD1 and either CD4 or CD8 are lost when $T$ lymphocytes migrate to the periphery. Reactive nodes and some cases of Hodgkin's disease may show a similar picture with an increase in infiltration with $\mathrm{T}$ lymphocytes. In this case gene rearrangement of the $T$ cell receptor finally confirmed the diagnosis of a clonal T cell malignancy.

Case 7 and 8 were both diagnosed as having B cell lymphoblastic lymphomas: case 7 by analysis of pleural fluid and biopsy of the abdominal mass and case 8 by analysis of a needle biopsy of liver. In both cases the cells had a primitive lymphoid morphology and all expressed CD10, CD19, and strong surface IgM. This phenotypic pattern is characteristic of B cell lymphoblastic lymphoma. The diagnoses were confirmed histologically.

In cases 9 and 10, a rapid diagnosis of $T$ cell lymphoblastic lymphoma was made on pleural fluid. Morphologically, the cells were small darkly staining and acid phosphatase staining showed characteristic polar positivity. Flow cytometry showed a uniform population of cells. Fluorescein labelled MoAbs to these cells showed them to be $C D 1, C D 2$, and $C D 3$ positive (fig 4). Using two different fluorochrome labels, fluoroscein and phycoerythrin, these cells were also shown to be CD4 and CD8 positive (fig 5). This combination of markers is seen only in thymic $\mathrm{T}$ cell malignancy as all of these antigens are acquired during intrathymic maturation. $\mathrm{CD} 1$ and either CD4 or CD8 are lost when T lymphocytes migrate to the periphery (as in case 6).

\section{Discussion}

This series of 10 patients describes the use of MoAbs and flow cytometry as a means of rapidly diagnosing haematological and solid malignancies of childhood. This technique has a number of advantages. Firstly, only a small sample is required as the analyses are performed on single cell suspensions and with adequate clinical information an appropriate small panel of MoAbs can be selected. Secondly, this method is extremely rapid and a diagnosis can be reached within less than three hours of receipt of the sample while conventional histology may take over 48 hours. This allows appropriate chemotherapy to be given early in cases where disease may progress rapidly such as lymphomas, ${ }^{9}$ which may also cause superior vena cava obstruction as seen in cases 9 and 10 , or where life threatening complications occur, such as the marked hypertension seen in case 3 . Thirdly, flow cytometry may give accurate information on both cell lineage and stage of differentiation of the tumour in the haematological malignancies. Finally, we have shown that the diagnostic accuracy of flow cytometry is good when compared with histological diagnosis (table). In only case 6 was there doubt about diagnosis using flow cytometry. Flow cytometry analysis on the initial biopsy failed to differentiate between reactive and malignant change, although histologically the biopsy was consistent with a $T$ cell lymphoma. Flow cytometry analysis on a further biopsy performed 15 weeks into treatment, however, clearly demonstrated malignant disease of $\mathrm{T}$ cell origin. This diagnosis was subsequently supported by gene rearrangement studies which showed a clonal $\mathrm{T}$ cell population.

We have clearly demonstrated the value of flow cytometry analysis in the rapid diagnosis of childhood malignancy. Tissue was obtained by needle biopsy in three of our eight patients. This is obviously an extremely important alternative to open surgical biopsy in critically ill patients. Though we have shown that accurate diagnosis by flow cytometry may be possible on very small biopsies, it must be remembered that such a sample may not be truly representative of the lesion. However, in our cases flow cytometry has provided valuable information on cell lineage, which has been important in the planning of appropriate treatment and the rapidity of diagnosis, and has allowed such treatment to be given early in life threatening situations. This study also highlights the importance of collecting fresh tissue, not only for analysis by flow cytometry, 
but now for other comprehensive analyses, such as cytogenetics, gene rearrangements, the study of proliferation indices, ${ }^{10}$ and multidrug resistance, " all of which may be of great importance in determining the prognosis in childhood malignancy.

1 Chan LC, Pegram SM, Greaves MF. Contribution of immunophenotype to the classification and differential diagnosis of acute leukaemia. Lancet 1985; i: 475-9.

2 Zeltzer PM, Bodey B, Marlin A, Kemshead J. Immunophenotype profile of childhood medulloblastomas and phenotype profition monoclonal antibodies. Cancer 1990; 66: 273-83.

3 Kaplan SS, Penchansky L, Stolc V, Contis L, Krause JR. Immunophenotyping in the classification of acute Immunophenotyping in the classificatio

4 Shapiro HM. Practical flow cytometry. 2nd Ed. New York: Alan R Liss, 1988.

5 Rosenberg SA, Packard BS, Aebersold PM. Use of tumour infiltrating lymphocytes and interleukin-2 in the immuno- therapy of patients with metastatic melanoma. $N$ Engl $\mathcal{F}$ Med 1988; 319: 1676-80.

6 Wimperis JZ, Brandt LJ, O'Connor S, Marcus R, Broadbent $V$. Unusual presentation of cALL antigen positive extramedullary disease in childhood; a report of two cases with solated masseter muscle involvement. Cancer (in press).

7 Allan PM, Garson GA, Harper EI, et al. Biochemical characterisation and clinical applications of a monoclonal antibody recognising an antigen restricted to neuroectodermal tissues. Int $\mathcal{F}$ Cancer 1983; 31: 591-8.

8 Gerdes J, Lemke H, Baisch H, Wacker HH, Schwab U, Stein $\mathrm{H}$. Cell cycle analysis of a cell proliferation-associated human nuclear antigen defined by the monoclonal antibody Ki-67. F Immunol 1984; 133: 1710-5.

9 Eliasson JK, Rajagopal KR, Dow NS. Respiratory failure in rapidly progressing pulmonary lymphoma. Use of immunophenotyping in diagnosis. Am Rev Respir Dis 1990; 141: $231-4$.

10 Girino M, Riccardi A, Danova M, et al. Immunocytochemical evaluation of proliferative activity in human brain tumours. evaluation of proliferative activity in
Anal Cell Pathol 1990; 2: 269-75.

11 Chan HS, Thorner PS, Haddad G, Ling V. Immunohistochemical detection of P-glycoprotein: prognostic correlation 689-704. 